Article

\title{
Optimization and Modeling of Slightly Acidic Electrolyzed Water for the Clean-in-Place Process in Milking Systems
}

\author{
Yu Liu ${ }^{1,2}$, Chaoyuan Wang ${ }^{1,2, *(\mathbb{C})}$, Zhengxiang Shi ${ }^{1,2}$ and Baoming $\mathrm{Li}^{1,2}(\mathbb{D})$ \\ 1 Department of Agricultural Structure and Bioenvironmental Engineering, College of Water Resources and \\ Civil Engineering, China Agricultural University, Beijing 100083, China; xiaohaizhibei@cau.edu.cn (Y.L.); \\ shizhx@cau.edu.cn (Z.S.); libm@cau.edu.cn (B.L.) \\ 2 Key Laboratory of Agricultural Engineering in Structure and Environment, Ministry of Agriculture and \\ Rural Affairs, Beijing 100083, China \\ * Correspondence: gotowchy@cau.edu.cn; Tel.: +86-10-6273-8635
}

Received: 7 October 2020; Accepted: 16 November 2020; Published: 18 November 2020

\begin{abstract}
To find an environmentally friendly and energy efficient alternative to acidic detergent for a milking system clean-in-place (CIP) process, this study investigated the feasibility of applying slightly acidic electrolyzed water (SAEW) alone to wash the system by cleaning soiled stainless steel (304) pipes, rubber gaskets, and PVC milk hoses, which were used in the milking system. The results showed that SAEW with appropriate parameters could achieve the same or even better hygienic effects compared with commercial detergent. Using response surface models, the SAEW parameters required to clean stainless steel were optimized at $9.9 \mathrm{~min}$ for the treatment time, $37.8^{\circ} \mathrm{C}$ for the water temperature, and $60 \mathrm{mg} / \mathrm{L}$ for the available chlorine concentration; and were $14.4 \mathrm{~min}$, $29.6{ }^{\circ} \mathrm{C}$, and $60 \mathrm{mg} / \mathrm{L}$ for rubber gasket and PVC samples, respectively. After washing with the optimized parameter combination, bacteria and adenosine triphosphate on the three materials were almost non-detectable, indicating that SAEW has the potential to replace acidic detergents in CIP milking systems.
\end{abstract}

Keywords: slightly acidic electrolyzed water; response surface model; milking system; sanitation

\section{Introduction}

Cleaning and disinfection are critical operations in dairy farming. On a commercial dairy farm, the clean-in-place (CIP) process is a standard process of the milking system, consisting of four cycles: (1) prewashing with warm water; (2) circular washing with alkaline chemical detergent; (3) circular washing with acidic chemical detergent; (4) sanitizing with sanitizing detergent before the next milking phase [1]. The commercially used detergents in the CIP process typically contain sodium hydroxide, sulfuric acid, or phosphoric acid, which are highly caustic and can cause serious burns to the skin and mucous membrane [2-5]. Moreover, detergent residues in raw milk seriously affect the milk quality and reputation of the farms, which consequently lead to heavy economic losses to the farmers [6].

Under such circumstances, research endeavors have been conducting to optimize the CIP protocols and find alternative detergents. Studies have shown that the optimization of cleaning protocols, aimed at minimizing the consumption of energy and chemical detergent, depends on the type of soils, surfaces, and materials to be cleaned [7]. For the milking system, Vilar et al. [8] found that weekly cleaning with acidic chemical detergent achieved a better hygienic environment than daily cleaning. Liu et al. [9] suggested that using alkaline and acidic detergent alternately to clean the milk tank could help maintain a level of good hygiene and save water and costs. Overall, it is not suggested to apply alkaline and acidic chemical detergents together in one cleaning procedure, especially for 
equipment with clod surfaces, such as milking systems, because of the associated corrosivity, energy use, and complexity of the discharged water treatment afterward [10]. Therefore, finding an alternative that is suitable for interchangeable use to replace these chemicals on sites would be highly advantageous to farmers.

Electrolyzed water (EW), as a novel cleaning and sanitizing agent, has been widely applied in food and medical industries [11,12]. EW can be disposed back into the environment after usage, contributing to decreasing the amount of halogenated compounds that accumulate in the environment, as highlighted by the U.S. Environmental Protection Agency [13]. An EW generator with a semipermeable membrane can produce both alkaline electrolyzed water ( $\mathrm{pH}$ of 11.5) and acidic electrolyzed water (AEW, $\mathrm{pH}$ of 2.6) at the cathode and anode in the same process, respectively [14], and the characteristics of both solutions theoretically satisfy the requirements for alkaline and acidic chemical detergents in cleaning the milking system [2]. Studies in the laboratory have shown that using alkaline electrolyzed water ( $\mathrm{pH}$ of 11.5) and AEW ( $\mathrm{pH}$ of 2.6) together in a complete CIP process could achieve an equivalent or even better cleaning effect $[2,5,15-17]$. However, the practical challenge of using alkaline electrolyzed water and AEW together is the higher corrosivity. To optimize this protocol, Liu et al. [18] showed that alkaline electrolyzed water as an alternative to alkaline chemical detergents could be used alone in standardized CIP processes for milking systems.

Meanwhile, an EW generator without a semipermeable membrane produced slightly acidic electrolyzed water (SAEW, $\mathrm{pH}$ of 5.0-6.5) in one study [19]. Another study showed that AEW corrosivity decreased by more than $50 \%$, with the $\mathrm{pH}$ increasing from 2.42 to 6.12 [20], and the strong oxidability and good sterilization ability of the SAEW were also revealed [21-23]. Additionally, the consumption of energy to produce SAEW is $50 \%$ less than that needed to produce the same quantity of AEW due to the different membrane structures. Theoretically, SAEW meets the standards for an acidic detergent alternative in the CIP process, however its effectiveness in cleaning milking systems has not yet been tested. The chemicals used in the CIP process are toxic, dangerous, and expensive, while using SAEW will help eliminate many of the dangers and will be cost-effective. The successful application of SAEW alone to wash milking systems would greatly benefit the optimization of the CIP cleaning protocols.

This work aimed to investigate the cleaning effect of using SAEW alone on three typical materials (stainless steel (304) pipes, rubber gaskets, and PVC milk hoses) that are often used in milking systems and to optimize the combinations of key parameters (treatment time, water temperature, and available chlorine concentration (ACC)) of the SAEW cleaning through response surface modeling.

\section{Materials and Methods}

\subsection{Bacterial Cultures}

This study selected Escherichia coli (ATCC25922) and Pseudomonas fluorescens (ATCC49642) as target bacteria, which can be easily found in raw milk. These two bacteria were collected from the China Veterinary Culture Collection (CVCC, Beijing, China and were cultured in $10 \mathrm{~mL}$ of tryptic soy broth (TSB, AOBOX Biotechnology Co. Ltd., Beijing, China) at $37^{\circ} \mathrm{C}$ for $24 \mathrm{~h}$. To ensure the culture broth had a bacterial population of $1 \times 10^{9} \mathrm{CFU} / \mathrm{mL}$, each sample of the broth was checked using an aerobic plate count (APC) method with tryptic soy agar (TSA, AOBOX Biotechnology Co. Ltd., Beijing, China) [15].

\subsection{Milk Preparation}

Raw milk was obtained from the Yulong dairy farm (Beijing, China). To increase the raw milk bacterial population, $1 \mathrm{~mL}$ of each culture broth was centrifuged at $4400 \times g$ for $4 \mathrm{~min}$ at $4{ }^{\circ} \mathrm{C}$ [15]. Two bacterial cells were resuspended together in $10 \mathrm{~mL}$ of raw milk with a mixer (WH-2, Shanghai Luxi Fenxiyiqi Co. Ltd., Shanghai, China). 


\subsection{Specimens Preparation}

Three typical materials used in milking systems, namely stainless steel (304) pipes, rubber gaskets, and PVC milk hoses, were prepared as specimens. For each material there were 12 specimens, which were cut into $10 \mathrm{~cm}^{2}$ pieces. Before every treatment, the specimens were cleaned and autoclaved at $121{ }^{\circ} \mathrm{C}$ for $20 \mathrm{~min}$.

To prepare contaminated specimens, $0.1 \mathrm{~mL}$ inoculated raw milk was evenly soiled on the whole surface of each specimen with a sterile glass-coated rod. Then, the specimens were dried using laminar flow for $2 \mathrm{~h}$ to evaporate all visible liquid. The initial concentrations of bacteria on stainless steel, rubber gasket, and PVC samples were 5.10-6.00 $\log _{10} \mathrm{CFU} / \mathrm{cm}^{2}, 5.23-5.94 \log _{10} \mathrm{CFU} / \mathrm{cm}^{2}$, and 3.00-5.64 $\log _{10} \mathrm{CFU} / \mathrm{cm}^{2}$, respectively.

\subsection{Response Surface Design and Validation}

A standard Box-Benken response surface design (Table 1) was utilized to select suitable combinations of treatment time, water temperature, and ACC for SAEW cleaning, which contained 15 experimental trials, with the center point experiment repeated three times. According to the results of pre-experiments, the ranges for treatment time (8-12 $\mathrm{min})$, water temperature $\left(20-40^{\circ} \mathrm{C}\right)$, and ACC $(40-60 \mathrm{mg} / \mathrm{L})$ for stainless steel pipe, and the ranges of treatment time (12-15 $\mathrm{min})$, water temperature $\left(20-30^{\circ} \mathrm{C}\right)$, and ACC (40-60 mg/L) for rubber gasket and PVC milk hose samples were determined. For each trial three replications were performed.

Table 1. Box-Benken response surface design.

\begin{tabular}{|c|c|c|c|c|c|c|c|c|c|}
\hline \multirow{2}{*}{ Trial } & \multicolumn{4}{|c|}{ Time (min) } & \multicolumn{2}{|c|}{$\begin{array}{l}\text { Temperature } \\
\left({ }^{\circ} \mathrm{C}\right)\end{array}$} & \multicolumn{2}{|c|}{$\mathrm{ACC}(\mathrm{mg} / \mathrm{L})$} & \multirow[b]{2}{*}{ PVC } \\
\hline & SS $^{1}$ & RG & PVC & SS & RG & PVC & SS & RG & \\
\hline 1 & 10 & 15 & 15 & 40 & 30 & 30 & 40 & 50 & 50 \\
\hline 2 & 8 & 15 & 15 & 30 & 25 & 25 & 40 & 60 & 60 \\
\hline 3 & 10 & 12 & 12 & 30 & 20 & 20 & 50 & 50 & 50 \\
\hline 4 & 8 & 12 & 12 & 40 & 25 & 25 & 50 & 60 & 60 \\
\hline 5 & 8 & 15 & 15 & 30 & 25 & 25 & 60 & 40 & 40 \\
\hline 6 & 8 & 13.5 & 13.5 & 20 & 25 & 25 & 50 & 50 & 50 \\
\hline 7 & 12 & 12 & 12 & 30 & 30 & 30 & 60 & 50 & 50 \\
\hline 8 & 12 & 13.5 & 13.5 & 40 & 30 & 30 & 50 & 40 & 40 \\
\hline 9 & 10 & 15 & 15 & 40 & 20 & 20 & 60 & 50 & 50 \\
\hline 10 & 10 & 13.5 & 13.5 & 30 & 20 & 20 & 50 & 40 & 40 \\
\hline 11 & 12 & 13.5 & 13.5 & 30 & 25 & 25 & 40 & 50 & 50 \\
\hline 12 & 10 & 13.5 & 13.5 & 20 & 20 & 20 & 40 & 60 & 60 \\
\hline 13 & 12 & 12 & 12 & 20 & 25 & 25 & 50 & 40 & 40 \\
\hline 14 & 10 & 13.5 & 13.5 & 20 & 30 & 30 & 60 & 60 & 60 \\
\hline 15 & 10 & 13.5 & 13.5 & 30 & 25 & 25 & 50 & 50 & 50 \\
\hline
\end{tabular}

An additional 6 trials with different parameters, which were not included in the model development, were carried out (Table 2) to confirm the adequacy of the models.

Table 2. Six trials with different parameters used to validate the models.

\begin{tabular}{cccc}
\hline Trial & Treatment Time (min) & Cleaning Temperature $\left({ }^{\circ} \mathbf{C}\right)$ & ACC $(\mathbf{m g} / \mathbf{L})$ \\
\hline 1 & 9 & 20 & 40 \\
2 & 9 & 30 & 50 \\
3 & 9 & 40 & 60 \\
4 & 11 & 20 & 60 \\
5 & 11 & 30 & 50 \\
6 & 11 & 40 & 40 \\
\hline
\end{tabular}




\subsection{Preparation of SAEW and Chemical Disinfectant}

SAEW samples with different ACC levels of 20, 30, 40, 50, and $60 \mathrm{mg} / \mathrm{L}$ were generated by electrolyzing $\mathrm{NaCl}$ solutions using a generator (Beijing Rui'ande Environment Technology Co. Ltd., Beijing, China) set at 5, 8,11,14, and $17 \mathrm{~A}$, respectively. The $\mathrm{pH}$ and oxidation-reduction potential (ORP) values of the SAEW were measured using a dual-scale meter (Hangzhou Ying'ao Technology Co., Hangzhou, China). The ACC was determined by a digital chlorine test kit (RC-2Z, Kasahara Chemical Instruments Co., Saitama, Japan). The chemical disinfectant was prepared at a concentration of $0.5 \%$ by diluting the concentrated acidic chemical detergent (Cidmax, DeLaval Co. Ltd., Tianjin, China; referred to as "super") with tap water following the manufacturer's instruction.

The SAEW and commercial acidic chemical detergent were heated in buckets with lids to the targeted temperature using a self-heating plate controlled by a single-channel thermal table (CH6E07, Beijing Kunlun Zhicheng Sensor Technology Co., Beijing, China).

\subsection{Disinfectant Treatments}

In order to check the cleaning potential when using SAEW alone, this study only performed the first and third steps of the standard CIP process (warm water rinsing and acidic chemical detergent washing) without disturbance from the final disinfection step. The cleaning process consisted of two cycles: (1) prewashing with $45^{\circ} \mathrm{C}$ warm water for $5 \mathrm{~min}$; and (2) washing with SAEW or "super".

The cleaning solution was poured into a $400 \mathrm{~mL}$ beaker without any agitation to simulate the worst case scenario for locations of slow flow in the milking system [15]. All prepared specimens were soaked in warm water, then transferred to the beakers containing SAEW or "super". The treatment temperature and time for "super" were $80^{\circ} \mathrm{C}$ and $8 \mathrm{~min}$, respectively, according to the manufacturer's recommendation. After treatment, specimens were taken out and sampled immediately.

\subsection{Bacterial Counting and Cleanliness Evaluation}

The soiling and hygiene levels of the specimens were evaluated before and after treatment with SAEW using the APC method and an adenosine triphosphate (ATP) bioluminescence test. The APC method is widely used to assess the cleanliness of food contact surfaces [8]. The ATP bioluminescence test is well suited to monitoring the cleanliness within hazard analysis critical control point (HACCP) systems [24]. It can be used for real-time assessment and can detect bacterial cells and food residues, which might affect the cleanliness and hygiene of food contact surfaces [25].

Six specimens of each material were checked for their original contamination levels, while the other six specimens were checked for effects after cleaning. Three specimens were swabbed for microbiological analysis using sterilized cotton swabs soaked with $0.1 \%$ peptone water, while the other three were swabbed for ATP bioluminescence testing using the method recommended by the Ministry of Health, China [26]. The details for the microbiology counting process were given by Liu et al. [18].

As for the ATP bioluminescence test, samples were collected by using ATP test swabs (Shandong Langrun Commerce CO. Ltd., Jinan, China). Then, the swabs were tested using a LUMinator-T portable analyzer (CF-420, Shanghai Canfu Jidian Co. Ltd., Shanghai, China) to detect the emitted light from the ATP, which was quantified in "relative light units" (RLUs).

The bacteria and ATP removal rates were used for CIP performance comparisons. The equations used to calculate the bacteria and ATP removal rates were as follows:

$$
\text { Bacteria removal rate }=\left(1-\frac{\text { Bacteria concentration after CIP }}{\text { Bacteria concentration before CIP }}\right) \times 100
$$

where the units for the bacteria removal rate and bacterial concentration were $\%$ and $\log _{10}$ $\mathrm{CFU} / \mathrm{cm}^{2}$, respectively.

$$
\text { ATP removal rate }=\left(1-\frac{A T P \text { value after } C I P}{A T P \text { value before } C I P}\right) \times 100
$$


where the units for the ATP removal rate and ATP value were \% and RLU, respectively.

\subsection{Statistical Analysis}

The bacteria population was expressed as $\log _{10} \mathrm{CFU} / \mathrm{cm}^{2}$. The mean values for the total aerobic bacteria and RLUs were calculated from the independent triplicate trials. A Box-Benken response surface design table was generated and the results were analyzed using Minitab 17 (Minitab, Inc., State College, PA, USA). Significant differences in mean values for bacteria removal and ATP from three materials were analyzed using least significant differences with repeated measurement analyses of variance (ANOVAs) and a 95\% confidence interval in SPSS 21.0 (SPSS, Inc., Chicago, IL, USA).

\section{Results and Discussion}

\subsection{Physicochemical Properties of Treatment Solutions}

The ACC, pH, and ORP values for the tap water, SAEW, and "super" are shown in Table 3. For SAEW, the ACC and ORP values ranged from 18 to 62 and from 732 to $924 \mathrm{mV}$, respectively. "Super" did not contain any ACC, because its effective elements were $\mathrm{H}_{2} \mathrm{SO}_{4}$ and $\mathrm{H}_{3} \mathrm{PO}_{4}$, and the $\mathrm{pH}$ value was 1.61 .

Table 3. Physicochemical properties of treatment solutions.

\begin{tabular}{cccc}
\hline Solutions & ACC $(\mathbf{m g} / \mathbf{L})$ & $\mathbf{p H}$ & ORP $(\mathbf{m} \mathbf{V})$ \\
\hline Tap water & $0 \pm 0$ & $7.65 \pm 0.01$ & $402 \pm 3$ \\
SAEW & $18 \pm 1$ & $6.25 \pm 0.04$ & $732 \pm 9$ \\
& $30 \pm 1$ & $6.30 \pm 0.07$ & $814 \pm 4$ \\
& $42 \pm 1$ & $5.88 \pm 0.05$ & $904 \pm 7$ \\
& $53 \pm 0$ & $6.25 \pm 0.11$ & $928 \pm 5$ \\
Super & $62 \pm 2$ & $6.00 \pm 0.02$ & $924 \pm 8$ \\
& $0 \pm 0$ & $1.61 \pm 0.01$ & $692 \pm 1$ \\
\hline
\end{tabular}

\subsection{SAEW Cleaning Efficiency in Removing Bacteria and ATP}

Table 4 illustrates that the disinfection efficacy values for SAEW with different cleaning parameters combinations varied a lot. It can be seen that in some conditions (trials $1,4,5,7,8$, 9, and 15 for stainless steel; trials 5, 7, 11, 12, 14, and 15 for rubber gaskets; trials 1, 2, 4, 5, 6, 7, 9, and 11 for PVC), SAEW treatments had similar or significantly higher $(p<0.05)$ bacterial disinfection efficiency as "super", as shown by the ATP values and bacteria counts (Table 4 ). These results indicated that SAEW used with appropriate parameter combinations for treatment time, water temperature, and ACC has the potential to be a cleaning agent for milking systems. The bacteria removal rates for stainless steel, rubber gasket, and PVC samples after using "super" were 99.98\%, 100.00\%, and 99.83\%; and ATP removal rates after using "super" were $69.70 \%, 93.07 \%$, and $94.04 \%$, respectively. Using SAEW with different combinations of treatment time, cleaning temperature, and ACC gave $100.00 \%$ bacterial and ATP removal rates. Bremer et al. [27] and Parkar et al. [28] also stated that the cleaning efficacy of CIP systems significantly depends on the exposure time, temperature, and cleaning agent concentration. Meanwhile, three materials treated with SAEW achieved a 5-log reduction in bacterial species, which corresponded with the definition of sanitization recommended by the Food and Drug Administration [29]. 
Table 4. Bacteria and ATP removal from three materials with the SAEW and "super" treatments.

\begin{tabular}{|c|c|c|c|c|c|c|c|}
\hline \multirow{2}{*}{ Solution } & \multirow{2}{*}{ Trial } & \multicolumn{3}{|c|}{ Removing Bacteria $\left(\log _{10} \mathrm{CFU} / \mathrm{cm}^{2}\right)$} & \multicolumn{3}{|c|}{ Removing ATP (RLU) } \\
\hline & & SS $^{1}$ & RG & PVC & SS & RG & PVC \\
\hline \multirow{15}{*}{ SAEW } & 1 & $6.00 \pm 0.00 * \mathrm{~b} 2$ & $5.45 \pm 0.00 * a$ & $5.64 \pm 0.00 * \mathrm{~b}$ & $265 \pm 0.00^{b}$ & $130 \pm 2.12^{b}$ & $420 \pm 0.71^{b}$ \\
\hline & 2 & $2.86 \pm 0.90^{\mathrm{b} 3}$ & $4.23 \pm 0.00^{b}$ & $3.18 \pm 0.00 * a$ & $225 \pm 0.71^{b}$ & $231 \pm 5.66^{b}$ & $405 \pm 0.71^{b}$ \\
\hline & 3 & $4.67 \pm 0.38^{\mathrm{a}}$ & $1.59 \pm 0.34^{b}$ & $4.18 \pm 1.07^{b}$ & $365 \pm 0.00^{b}$ & $115 \pm 0.00^{\mathrm{b}}$ & $360 \pm 2.12^{b}$ \\
\hline & 4 & $6.00 \pm 0.00 * b$ & $1.79 \pm 0.01^{b}$ & $3.18 \pm 0.00 * a$ & $265 \pm 0.00^{b}$ & $224 \pm 7.78^{b}$ & $399 \pm 0.71^{b}$ \\
\hline & 5 & $6.15 \pm 0.00 * b$ & $5.81 \pm 0.00 * b$ & $3.95 \pm 0.00 * \mathrm{~b}$ & $268 \pm 1.41^{b}$ & $225 \pm 0.71^{b}$ & $415 \pm 2.83^{b}$ \\
\hline & 6 & $2.50 \pm 0.01^{b}$ & $2.11 \pm 0.46^{b}$ & $3.02 \pm 0.34^{\mathrm{a}}$ & $120 \pm 0.71^{b}$ & $170 \pm 0.71^{b}$ & $415 \pm 1.41^{b}$ \\
\hline & 7 & $6.15 \pm 0.00 * b$ & $4.57 \pm 1.75^{\mathrm{a}}$ & $3.26 \pm 0.00^{\mathrm{a}}$ & $263 \pm 8.49^{b}$ & $220 \pm 2.83^{a}$ & $410 \pm 2.12^{b}$ \\
\hline & 8 & $6.00 \pm 0.00 * b$ & $5.56 \pm 0.00 * a$ & $3.98 \pm 0.00 * \mathrm{~b}$ & $270 \pm 0.00^{b}$ & $185 \pm 0.71^{b}$ & $325 \pm 1.41^{b}$ \\
\hline & 9 & $6.00 \pm 0.00 * b$ & $3.91 \pm 0.51^{b}$ & $4.29 \pm 1.91^{b}$ & $265 \pm 0.00^{b}$ & $125 \pm 0.71^{b}$ & $400 \pm 0.00^{b}$ \\
\hline & 10 & $4.67 \pm 0.38^{a}$ & $2.94 \pm 0.51^{b}$ & $3.98 \pm 0.00 * b$ & $355 \pm 2.12^{* b}$ & $165 \pm 0.00^{b}$ & $310 \pm 1.41^{b}$ \\
\hline & 11 & $4.60 \pm 0.71^{\mathrm{a}}$ & $5.81 \pm 0.00 * b$ & $3.95 \pm 0.00 * b$ & $230 \pm 0.00^{b}$ & $230 \pm 0.71^{b}$ & $455 \pm 0.71^{b}$ \\
\hline & 12 & $2.95 \pm 1.19^{b}$ & $5.44 \pm 0.70^{\mathrm{a}}$ & $4.29 \pm 0.00 * \mathrm{~b}$ & $215 \pm 0.00^{b}$ & $275 \pm 0.00^{b}$ & $303 \pm 0.71^{b}$ \\
\hline & 13 & $2.58 \pm 0.44^{b}$ & $3.05 \pm 0.91^{b}$ & $3.00 \pm 0.00 * a$ & $130 \pm 0.71^{b}$ & $170 \pm 0.71^{b}$ & $245 \pm 0.00^{b}$ \\
\hline & 14 & $4.48 \pm 2.36^{\mathrm{a}}$ & $5.94 \pm 0.00 * b$ & $4.29 \pm 0.00 * \mathrm{~b}$ & $267 \pm 0.71^{b}$ & $285 \pm 0.71^{b}$ & $313 \pm 2.12^{b}$ \\
\hline & 15 & $5.59 \pm 0.49^{b}$ & $5.46 \pm 0.50^{\mathrm{a}}$ & $2.00 \pm 1.41^{b}$ & $360 \pm 1.41^{b}$ & $220 \pm 2.12^{a}$ & $383 \pm 1.41^{b}$ \\
\hline Super & & $4.18 \pm 1.15^{\mathrm{a}}$ & $5.06 \pm 0.49^{a}$ & $2.83 \pm 0.50^{a}$ & $92 \pm 15.56^{a}$ & $219 \pm 5.66^{a}$ & $392 \pm 19.09^{\mathrm{a}}$ \\
\hline
\end{tabular}

${ }^{1} \mathrm{SS}=$ stainless steel pipe; RG = rubber gasket; $\mathrm{PVC}=\mathrm{PVC}$ milk hose. ${ }^{2 *}$ No detectable survivors. ${ }^{3}$ Different lowercase letter in each column indicate significant differences when comparing the items for "super" with the others at 0.05 level.

SAEW shows strong oxidability with effective elements (ACC) of $\mathrm{HClO}, \mathrm{ClO}^{-}$, and $\mathrm{Cl}_{2} . \mathrm{HClO}$ can kill bacteria by destroying the membrane, leading to leakage of the cytoplasmic content [30], protein denaturation, and stopping cellular metabolism [31]. Similarly, the disinfection efficiency of "super" is based on $\mathrm{H}_{2} \mathrm{SO}_{4}$ and $\mathrm{H}_{3} \mathrm{PO}_{4}$, causing protein denaturation in the bacterial cell wall. Although the bactericidal substances of the two cleaning solutions are different, the sterilizing mechanisms are similar. Hence, with appropriate selection of its parameters, SAEW could be used as an alternative to "super".

\subsection{Model Fitting}

Response surface models were used to predict $\log _{10}$ bacterial reductions and ATP removal rates from the milking system and to determine the parameters based on a predicted result. The coefficient of determination $\left(R^{2}\right)$ and lack of fit values for the 6 models are listed in Table 5 for $\log _{10}$ bacterial reduction and ATP removal rates, respectively. The significance of the lack of fit test shows the quality and accuracy of the fitness models; when the $p$-value is greater than 0.05 , the model is considered logical [32]. According to the regression analysis of all models, the significance levels of the models were $<0.05$, while the significance levels for lack of fit were $>0.05$, which showed that all models were logical. 
Table 5. Response surface models for $\log _{10}$ bacterial reductions and ATP removal rates for three typical materials in a milking system cleaned using SAEW.

\begin{tabular}{|c|c|c|c|c|c|}
\hline Materials & Removal Efficiency $^{1}$ & Models $^{2}$ & $\mathbf{R}^{2}$ & $p$ & $\begin{array}{c}\text { Lack of } \\
\text { Fit }\end{array}$ \\
\hline \multirow[t]{2}{*}{ Stainless steel } & $\log _{10}$ bacterial reduction & $\begin{array}{c}\mathrm{R}_{\mathrm{S}}=-6.240+0.802 \mathrm{x}_{1}+ \\
0.155 \mathrm{x}_{2}+0.040 \mathrm{x}_{3}-0.006 \mathrm{x}_{1} \mathrm{x}_{3} \\
-0.001 \mathrm{x}_{2} \mathrm{x}_{3}-0.024 \mathrm{x}_{1}^{2}- \\
0.001 \mathrm{x}_{2}^{2}+0.001 \mathrm{x}_{3}^{2}\end{array}$ & 0.90 & 0.05 & 0.24 \\
\hline & ATP removal rate & $\begin{array}{c}\mathrm{R}_{\mathrm{S}-\mathrm{ATP}}=-84.900+23.800 \mathrm{x}_{1}+ \\
3.590 \mathrm{x}_{2}-1.153 \mathrm{x}_{1}{ }^{2}-0.051 \mathrm{x}_{2}{ }^{2}\end{array}$ & 0.70 & 0.01 & 0.14 \\
\hline \multirow[t]{2}{*}{ Rubber gasket } & $\log _{10}$ bacterial reduction & $\begin{array}{c}\mathrm{R}_{\mathrm{R}}=-86.500+12.120 \mathrm{x}_{1}+ \\
0.191 \mathrm{x}_{2}-0.423 \mathrm{x}_{1}^{2}\end{array}$ & 0.56 & 0.03 & 0.97 \\
\hline & ATP removal rate & $\begin{array}{c}\mathrm{R}_{\mathrm{R}-\mathrm{ATP}}=-329+27.200 \mathrm{x}_{1}+ \\
21.950 \mathrm{x}_{2}-1.840 \mathrm{x}_{3}-0.381 \mathrm{x}_{1} \mathrm{x}_{2} \\
\quad+0.082 \mathrm{x}_{1} \mathrm{x}_{3}-0.034 \mathrm{x}_{2} \mathrm{x}_{3}- \\
0.787 \mathrm{x}_{1}^{2}-0.285 \mathrm{x}_{2}^{2}+0.016 \mathrm{x}_{3}^{2}\end{array}$ & 0.94 & 0.01 & 0.57 \\
\hline \multirow[t]{2}{*}{ PVC } & $\log _{10}$ bacterial reduction & $\begin{array}{c}\mathrm{R}_{\mathrm{P}}=51.000-1.605 \mathrm{x}_{1}- \\
3.123 \mathrm{x}_{2}+0.076 \mathrm{x}_{1} \mathrm{x}_{2}+0.042 \mathrm{x}_{2}^{2}\end{array}$ & 0.70 & 0.01 & 0.99 \\
\hline & ATP removal rate & $\begin{array}{c}\mathrm{R}_{\mathrm{P}-\mathrm{ATP}}=-411+42.500 \mathrm{x}_{1}+ \\
15.500 \mathrm{x}_{2}+0.153 \mathrm{x}_{3}-0.488 \mathrm{x}_{1} \mathrm{x}_{2} \\
-1.055 \mathrm{x}_{1}^{2}-0.164 \mathrm{x}_{2}^{2}\end{array}$ & 0.85 & 0.01 & 0.05 \\
\hline
\end{tabular}

Note: ${ }^{1}$ The unit of the $\log _{10}$ bacterial reduction model is $\log _{10} \mathrm{CFU} / \mathrm{cm}^{2}$, while that of the ATP removal rate model is $\% .{ }^{2} x_{1}$ is the treatment time in $\min ; x_{2}$ is the temperature in ${ }^{\circ} \mathrm{C} ; \mathrm{x}_{3}$ is the ACC in $\mathrm{mg} / \mathrm{L}$.

Among these models, ACC only had a significant and positive effect on $\log _{10}$ bacterial reduction for stainless steel $(p<0.05)$. Moreover, all models were greatly affected by treatment time and temperature with SAEW ( $p<0.05)$. SAEW at an ACC of $40 \mathrm{mg} / \mathrm{L}$ reduced the Escherichia coli with $0.3 \%$ bovine serum albumin to undetectable levels after $10 \mathrm{~min}$ treatment, and it was reduced to an undetectable level with SAEW at an ACC level of $60 \mathrm{mg} / \mathrm{L}$ after $5 \mathrm{~min}$ treatment [33]. In this study, two bacteria (Escherichia coli and Pseudomonas fluorescens) were inoculated into the raw milk, and the lowest treatment time and ACC set for cleaning stainless steel were $8 \mathrm{~min}$ and $40 \mathrm{mg} / \mathrm{L}$, respectively, explaining why more time and higher ACC were needed to achieve satisfactory hygiene levels. As for rubber gasket and PVC samples, the treatment time (12-15 $\mathrm{min}$ ) was enough to diminish the leading role of the ACC. Thus, the determination of the three parameters of SAEW is very crucial to achieve a more satisfactory CIP performance because of the interaction effects of treatment time, water temperature, and ACC.

Davidson et al. [34] illustrated that ATP bioluminescence techniques were more sensitive than traditional plate counts for determining surface hygiene. The response surface plots for stainless steel, rubber gasket, and PVC ATP removal rates showed the cleaning effects of treatment time and cleaning temperature (Figure 1).

From the trends of the plots and the statistical analyses, the treatment time and cleaning temperature of SAEW within a certain interval significantly and positively $(p<0.05)$ affected the ATP removal rate for the three materials. With the treatment time increasing, the SAEW water flow could remove deposits more easily. Most of the minerals contained in the milk were acid-soluble [16], which could be removed more effectively with a long SAEW treatment. Water temperature affects the removal of bacteria and the ATP response within a certain range. Increasing the water temperature would enhance the molecular kinetic energy of the ACC to increase the contact opportunity with soils, which could remove more contaminants, as proven by Walker et al. [5,15]. The increase in temperature would result in more ACC being released to air, thus decreasing the sterilization effect of SAEW, especially when the temperature is over $45^{\circ} \mathrm{C}$ [2]. 


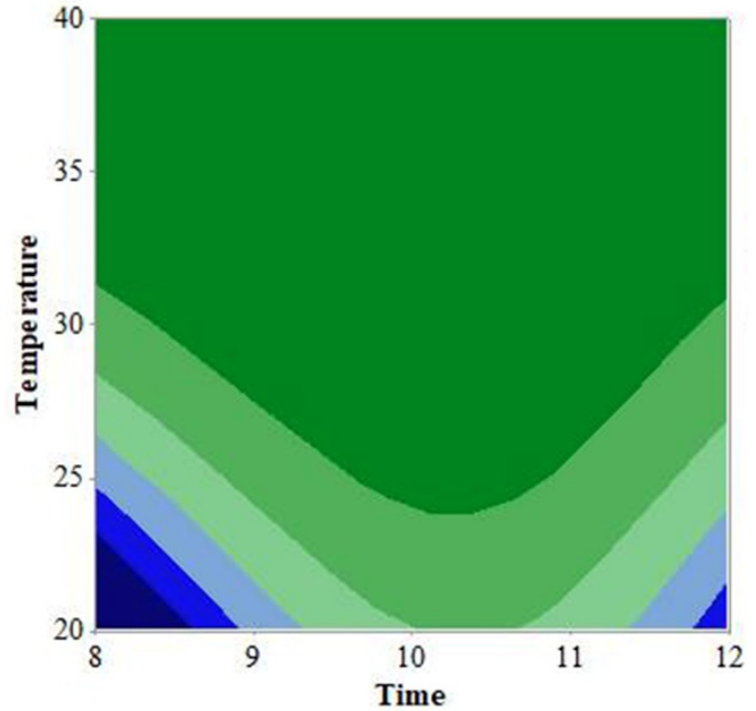

(a)

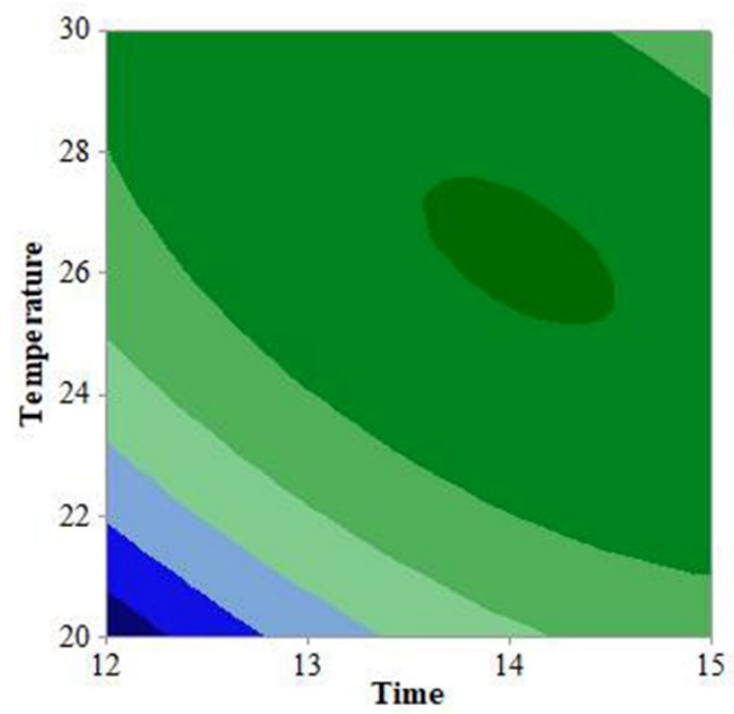

(c)

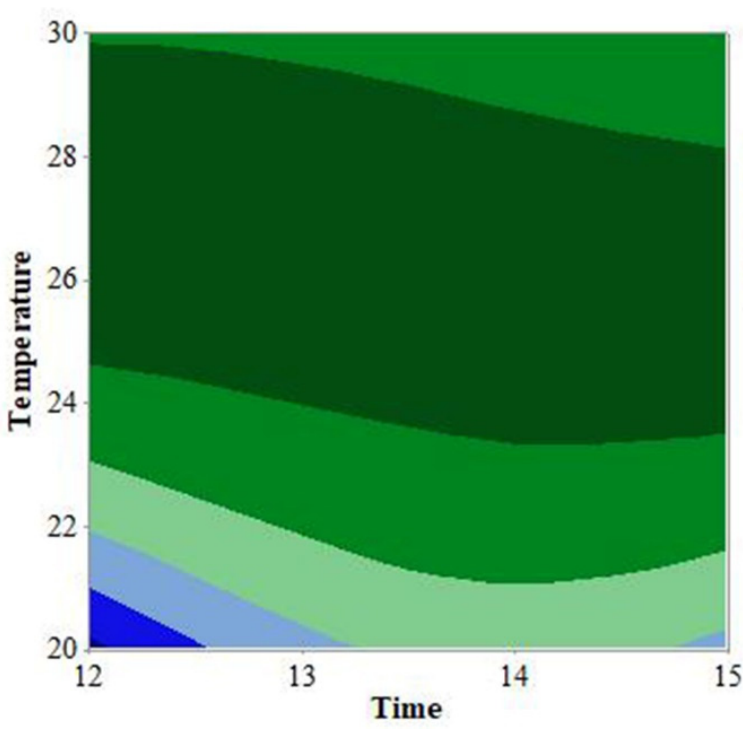

(b)

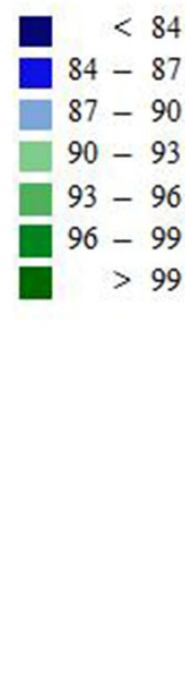

$<84$

$84-87$

$-90$

$-93$

99

Figure 1. Response surface plots showing the effects of treatment time and cleaning temperature on stainless steel, rubber gasket, and PVC ATP removal rates (\%) at an ACC of $50 \mathrm{mg} / \mathrm{L}$. (a) Stainless steel; (b) Rubber gasket; (c) PVC.

\subsection{Validation of the Models}

To validate the models, six additional random trials (Table 2) were carried out. The selected parameters were a treatment time range of 8 to $12 \mathrm{~min}$, temperature range of 20 to $40^{\circ} \mathrm{C}$, and ACC range of 40 to $60 \mathrm{mg} / \mathrm{L}$ for stainless steel. Rubber gasket and PVC samples had a treatment time range of 12 to $15 \mathrm{~min}$, temperature range of 20 to $30^{\circ} \mathrm{C}$, and ACC range of 40 to $60 \mathrm{mg} / \mathrm{L}$. The results matched with the predicted results (Figure 2). The $\mathrm{R}^{2}$ values of $\log _{10}$ bacterial reduction models for stainless steel, rubber gasket, and PVC samples were $0.98,0.93,0.96$; and the $\mathrm{R}^{2}$ values for the ATP removal rate models for the three materials were $0.91,0.91$, and 0.99 , respectively. It was concluded that the models were able to reliably predict $\log _{10}$ bacterial reduction and ATP removal rates for the three typical materials used in the milking system with SAEW treatment. 


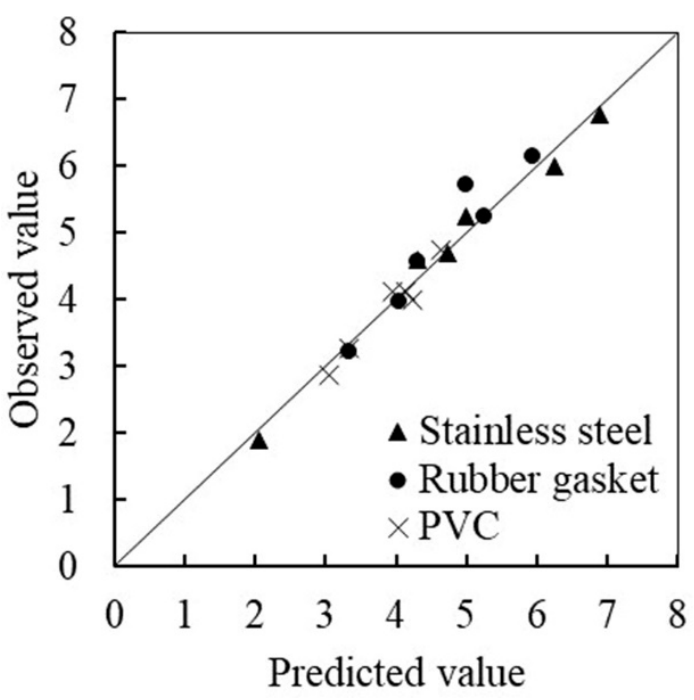

(a)

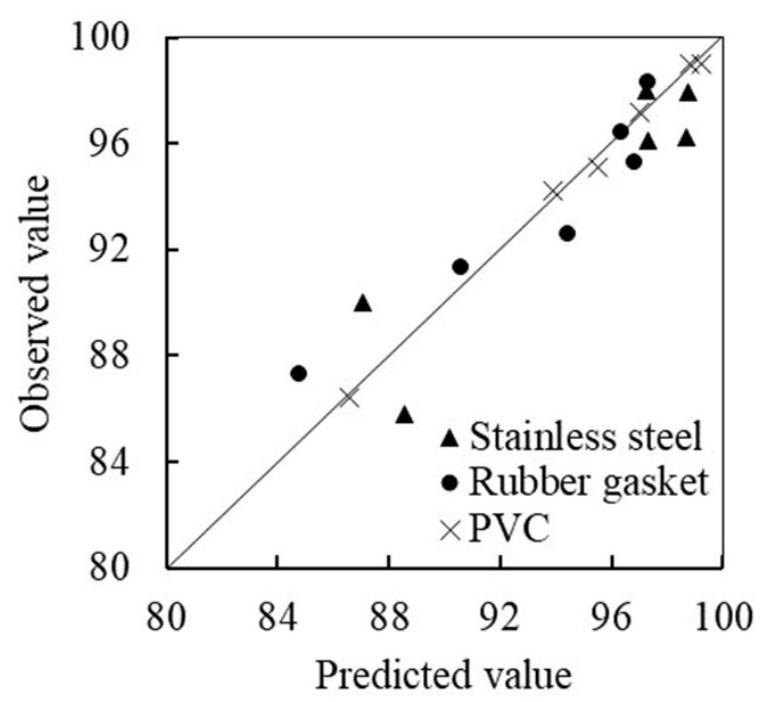

(b)

Figure 2. Observed and predicted bacterial reduction and ATP removal rates for three materials under 6 additional random experiments: (a) bacterial reduction $\left(\log _{10} \mathrm{CFU} / \mathrm{cm}^{2}\right)$; (b) ATP removal rate (\%).

\subsection{Optimization and Validation of SAEW Cleaning Parameters}

With the developed models, the SAEW parameters used to clean the milking system could be predicted and optimized to achieve $7.0 \log _{10} \mathrm{CFU} / \mathrm{cm}^{2}$ bacterial reduction and $100 \%$ ATP removal rate on the surfaces (Table 6). The optimized SAEW treatment time, cleaning temperature, and ACC needed to clean stainless steel were $9.9 \mathrm{~min}, 37.8^{\circ} \mathrm{C}$, and $60 \mathrm{mg} / \mathrm{L}$, respectively, similar to the parameters recommended by Dev et al. [2], who gave an optimized cleaning time of $10 \mathrm{~min}$ and temperature of $39.8^{\circ} \mathrm{C}$ for $\mathrm{AEW}(\mathrm{pH}=2.6, \mathrm{ACC}=80 \mathrm{ppm}$ ) in order to sanitize a stainless steel pipe in a milking system, however the corrosivity of AEW is 2 times greater than that of SAEW [20], which is believed to decrease the life of a milking system. Additionally, it seems that the bactericidal capability of SAEW is also higher than that of AEW because of its lower cleaning temperature and ACC. Stainless steel is easier to clean than rubber and PVC [16]. It can be seen in Table 6 that the treatment times for rubber gasket and PVC milk hose samples were longer than those for stainless steel pipe samples. Rubber has microscopic caverns and crevices on its surface, which make it harder to achieve a good hygiene level when cleaning $[17,35]$. Practically, it is recommended to inspect and replace the rubber materials twice a year on a dairy farm to prevent the rubber from aging and becoming more porous [1]. It is shown in Table 6 that the optimized SAEW cleaning parameters needed for rubber gasket and PVC samples were similar. In order to simplify the operation to produce suitable SAEW, the treatment time, cleaning temperature, and ACC were optimized based on the models of rubber gasket and PVC samples with the levels needed to clean these two materials, which were $14.4 \mathrm{~min}, 29.6^{\circ} \mathrm{C}$, and $60 \mathrm{mg} / \mathrm{L}$, respectively. These optimized SAEW parameters are applicable to dairy equipment with cold surfaces made with the same materials, such as piping systems, milk tanks, cryogenic milk trucks, and other equipment.

Table 6. Optimized parameters of SAEW treatments predicted by the models.

\begin{tabular}{cccc}
\hline Material & Treatment Time $(\mathbf{m i n})$ & Cleaning Temperature $\left({ }^{\circ} \mathbf{C}\right)$ & ACC $(\mathbf{m g} / \mathbf{L})$ \\
\hline Stainless steel pipe & 9.9 & 37.8 & 60 \\
Rubber gasket & 13.8 & 28.5 & 40 \\
PVC milk hose & 14.9 & 30 & 60 \\
Combining rubber & 14.4 & 29.6 & 60 \\
and PVC & & & \\
\hline
\end{tabular}


Three materials were cleaned using SAEW with the optimized parameters in order to verify the cleaning effects, which were compared with the results for the "super" treatment and its recommended solution properties (Figure 3). For SAEW, the bacteria and ATP removal rates were close to $100 \%$ for all three materials. Although the SAEW could not achieve the removal goals for bacteria and ATP in each treatment, it always had an equal or better effect as commercial detergents. This suggests that SAEW has potential as a replacement for typical commercial acidic chemical detergents for cleaning of milking systems. Meanwhile, the SAEW could be considered to be interchangeable use alkaline electrolyzed water in the CIP process, which would be environmentally friendly and highly advantageous to farmers $[9,18]$.

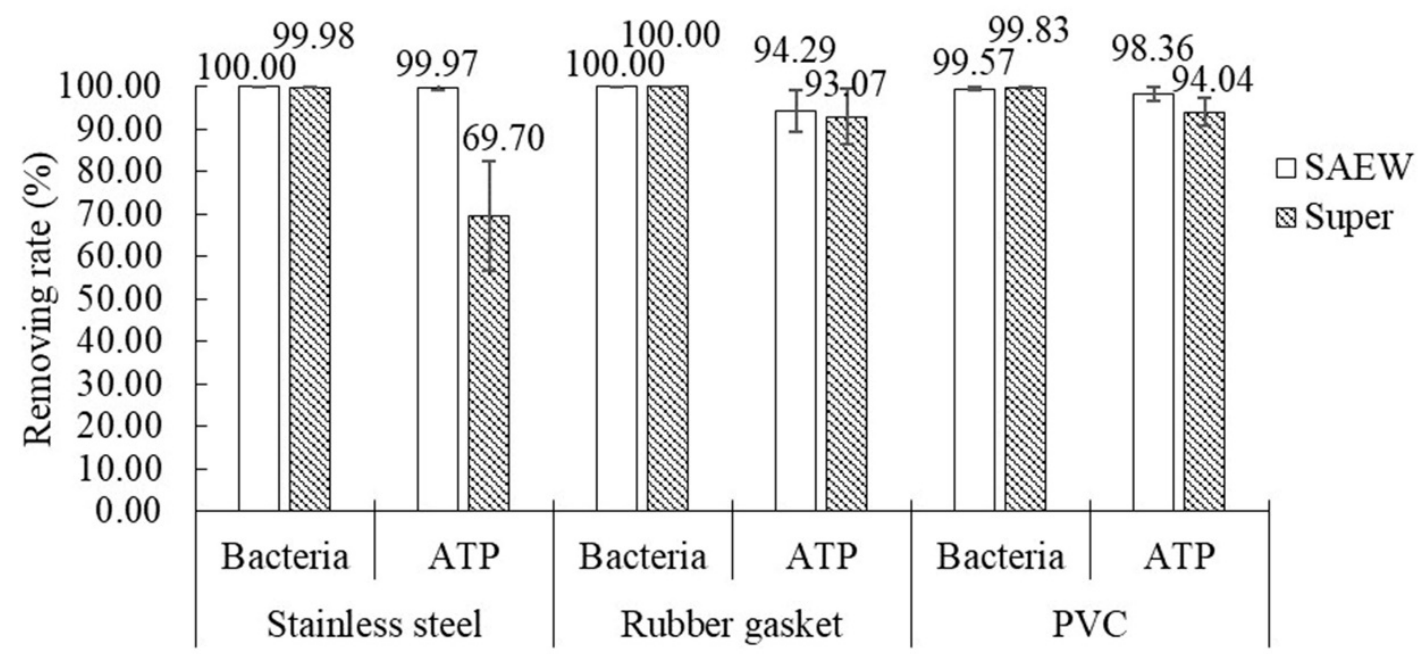

Figure 3. Comparison of bacteria and ATP removal rates for three materials after treatment with SAEW using the optimized parameters and commercial detergent ("super"). The required SAEW treatment time, cleaning temperature, and ACC were $9.9 \mathrm{~min}, 37.8^{\circ} \mathrm{C}$, and $60 \mathrm{mg} / \mathrm{L}$ to clean stainless steel; and were $14.4 \mathrm{~min}, 29.6^{\circ} \mathrm{C}$, and $60 \mathrm{mg} / \mathrm{L}$ to clean rubber gasket and PVC samples, respectively.

\section{Conclusions}

This study simulated a worst case scenario for the CIP process in a milking system, with low flow when rinsing with warm water and washing with acidic solution, in order to check the cleaning effects of SAEW on stainless steel, rubber gasket, and PVC hose samples, involving laboratory trials with appropriate combinations of treatment time, water temperature, and ACC. Compared to chemical detergent, the SAEW showed significantly higher bactericidal properties in conventional CIP steps, which suggested its potential for being a cleaning and bacteria removal agent for milking systems. For stainless steel, the cleaning SAEW parameters were optimized at $9.9 \mathrm{~min}$ (treatment time), $37.8^{\circ} \mathrm{C}$ (temperature), and $60 \mathrm{mg} / \mathrm{L}$ (ACC); and were $14.4 \mathrm{~min}, 29.6^{\circ} \mathrm{C}$, and $60 \mathrm{mg} / \mathrm{L}$ for rubber gasket and PVC samples, respectively. The cleaning effect and stability of SAEW need to be verified in a real CIP system in the future.

Author Contributions: Conceptualization, C.W.; formal analysis, Y.L.; methodology, C.W., Z.S., and B.L.; project administration, C.W.; writing-original draft preparation, Y.L.; writing-review and editing, C.W. All authors have read and agreed to the published version of the manuscript.

Funding: This research was funded by the National Key Research and Development Program (grant numbers: 2017YFD0701602, 2018YFD0500700); the National High Technology Research and Development Program (grant number: 2013AA10230602); and the China Agricultural Research System (grant number: CARS-36).

Conflicts of Interest: The authors declare no conflict of interest. 


\section{References}

1. DPC. Guidelines for Installation, Cleaning, and Sanitizing of Large and Multiple Receiver Parlor Milking Systems; Dairy Practices Council Publication: Pandora, OH, USA, 2010.

2. Dev, S.R.S.; Demirci, A.; Graves, R.E.; Puri, V.M. Optimization and modeling of an electrolyzed oxidizing water based Clean-In-Place technique for farm milking systems using a pilot-scale milking system. J. Food. Eng. 2014, 135, 1-10. [CrossRef]

3. HICAHS. The High Plains Intermountain Center for Agricultural Health and Safety-Factsheets, Colorado State University. Children on the Farm. Available online: http://www.hicahs.colostate.edu (accessed on 15 June 2012).

4. Jiménez-Pichardo, R.; Regalado, C.; Castaño-Tostado, E.; Meas-Vong, Y.; Santos-Cruz, J.; García-Almendárez, B.E. Evaluation of electrolyzed water as cleaning and disinfection agent on stainless steel as a model surface in the dairy industry. Food Control. 2016, 60, 320-328. [CrossRef]

5. Walker, S.P.; Demirci, A.; Graves, R.E.; Spencer, S.B.; Roberts, R.F. Cleaning milking systems using electrolyzed oxidizing water. Trans. ASAE 2005, 48, 1827-1833. [CrossRef]

6. Davey, K.R.; Chandrakash, S.; O'Neill, B.K. A new risk analysis of clean-in-place milk processing. Food Control. 2013, 29, 248-253. [CrossRef]

7. Suárez, L.; Díez, M.A.; García, R.; Riera, F.A. Membrane technology for the recovery of detergent compounds: A review. J. Ind. Eng. Chem. 2012, 18, 1859-1873. [CrossRef]

8. Vilar, M.J.; Rodríguez-Otero, J.L.; Diéguez, F.J.; Sanjuán, M.L.; Yus, E. Application of ATP bioluminescence for evaluation of surface cleanliness of milking equipment. Int. J. Food. Microbiol. 2008, 125, 357-361. [CrossRef] [PubMed]

9. Liu, Y.; Wang, C.Y.; Shi, Z.X.; Li, B.M. Disinfection effect and cleaning mode determination for milk tank using electrolyzed water. Trans. CSAE. 2017, 33, 300-306, (In Chinese with English Abstract). [CrossRef]

10. Zhang, X.J.; Cao, H.F.; Qi, X.M.; Wang, C.Y.; Liu, H.F.; Yun, Z.Y. Research progress of cleaning sanitization methods and effect detection for dairy production equipment. China Dairy Ind. 2015, 43, 49-51, (In Chinese with English Abstract).

11. Suzuki, T.; Itakura, J.; Watanabe, M.; Ohta, M.; Sato, Y.; Yamaya, Y. Inactivation of Staphylococcal enterotoxin-A with an electrolyzed anodic solution. J. Agric. Food. Chem. 2002, 50, 230-234. [CrossRef]

12. Suzuki, T.; Noro, T.; Kawamura, Y.; Fukunaga, K.; Watanabe, M.; Ohta, M.; Sugiue, H.; Sato, Y.; Kohno, M.; Hotta, K. Decontamination of aflatoxin-forming fungus and elimination of aflatoxin mutagenicity with electrolyzed $\mathrm{NaCl}$ anode solution. J. Agric. Food. Chem. 2002, 50, 633-641. [CrossRef]

13. U.S. Environmental Protection Agency. Overview of the Ecological Risk Assessment Process in the Office of Pesticide Programs, U.S. Environmental Protection Agency; U.S. Environmental Protection Agency, Office of Pesticide Programs: Washington, DC, USA, 2004.

14. Kim, C.; Hung, Y.; Brackett, R.E. Roles of oxidation-reduction potential in electrolyzed oxidizing and chemically modified water for inactivation of food related pathogens. J. Food. Protect. 2000, 63, 19-24. [CrossRef] [PubMed]

15. Walker, S.P.; Demirci, A.; Graves, R.E.; Spencer, S.B.; Roberts, R.F. Response surface modelling for cleaning and disinfecting materials used in milking systems with electrolyzed oxidizing water. Int. J. Dairy. Technol. 2005, 58, 65-73. [CrossRef]

16. Wang, X.M.; Demirci, A.; Puri, V.M.; Graves, R.E. Evaluation of blended electrolyzed oxidizing water-based cleaning-in-place (CIP) technique using a laboratory-scale milking system. Trans. ASABE 2016, 59, 359-370. [CrossRef]

17. Wang, X.M.; Puri, V.M.; Demirci, A.; Graves, R.E. One-step cleaning-in-place for milking systems and mathematical modeling for deposit removal from stainless steel pipeline using blended electroloyzed oxidizing water. Trans. ASABE 2016, 59, 1893-1904. [CrossRef]

18. Liu, Y.; Wang, C.Y.; Shi, Z.X.; Li, B.M. Cleaning and bacteria removal in milking systems by alkaline electrolyzed oxidizing water with response surface design. Trans. ASABE 2019, 62, 1251-1258. [CrossRef]

19. Gil, M.I.; Gómez-López, V.M.; Hung, Y.C.; Allende, A. Potential of electrolyzed water as an alternative disinfectant agent in the fresh-cut industry. Food. Bioprocess. Tech. 2015, 8, 1336-1348. [CrossRef]

20. Ayebah, B.; Hung, Y.C. Electrolyzed water and its corrosiveness on various surface materials commonly found in food processing facilities. J. Food. Process. Eng. 2005, 28, 247-264. [CrossRef] 
21. Abadias, M.; Usall, J.; Anguera, M.; Solsona, C.; Vinas, I. Efficacy of neutral electrolyzed water (NEW) for reducing microbial contamination on minimally processed vegetables. Int. J. Food. Microbiol. 2008, 31, 121-129. [CrossRef]

22. Hao, J.X.; Liu, H.; Liu, R.U.I.; Dalai, W.; Zhao, R.; Chen, T.; Li, L.T. Efficacy of slightly acidic electrolyzed water (SAEW) for reducing microbial contamination on fresh-cut cilantro. J. Food. Safety. 2010, 31, 28-34. [CrossRef]

23. Issa-Zacharia, A.; Kamitani, Y.; Morita, K.; Wasaki, K. Sanitization potency of slightly acidic electrolyzed water against pure cultures of Escherichia coli and Staphylococcus aureus, in comparison with that of other food sanitizers. Food Control. 2010, 21, 740-745. [CrossRef]

24. Aycicek, H.; Oguz, U.; Karci, K. Comparison of results of ATP bioluminescence and traditional hygiene swabbing methods for the determination of surface cleanliness at a hospital kitchen. Int. J. Hyg. Environ. Health 2006, 209, 203-206. [CrossRef] [PubMed]

25. Samkutty, P.J.; Gough, R.H.; Adkinson, R.W.; McGrew, P. Rapid assessment of the bacteriological quality of raw milk using ATP bioluminescence. J. Food. Protec. 2001, 64, 208-212. [CrossRef] [PubMed]

26. NHFPC. Food Enterprise HACCP Implementation Guide; NHFPC: Beijing, China, 2006. Available online: https: //www.jdzx.net.cn/article/402881e40c5730e0010c86c90f25006b/2015/11/402881e40c5730e0010c86e3c1be0087. html (accessed on 19 June 2006). (In Chinese)

27. Bremer, P.J.; Monk, I.; Butler, R. Inactivation of Listeria monocytogenes/ Flavobacterium spp. biofilm using chlorine: Impact of substrate, $\mathrm{pH}$, time and concentration. Lett. Appl. Microbiol. 2002, 35, 321-325. [CrossRef] [PubMed]

28. Parkar, S.G.; Flint, S.H.; Brooks, J.D. Evaluation of the effect of cleaning regimes on biofilms of thermophilic bacilli on stainless steel. J. Appl. Microbiol. 2004, 96, 110-116. [CrossRef] [PubMed]

29. U.S. Food and Drug Administration. Food Code; U.S. Food and Drug Administration: Silver Spring, MD, USA, 2005.

30. Mokgatla, R.M.; Gouws, P.A.; Brozel, V.S. Mechanisms contributing to hypochlorous acid resistance of a Salmonella isolate from a poultry-processing plant. J. Appl. Microbiol. 2002, 92, 566-573. [CrossRef]

31. Chen, G.Q.; Li, A.B.; Liang, J.J.; Zhou, S.H.; Zhu, Y.K.; Huang, W.; Yu, Y. Experimental study on germicidal efficacy and its influencing factors of electrolyzed oxidizing water. Pract. Prev. Med. 2001, 8, 269-271, (In Chinese with English Abstract).

32. Zang, Y.T.; Li, B.M.; Bing, S.; Cao, W. Modeling disinfection of plastic poultry transport cages inoculated with Salmonella enteritids by slightly acidic electrolyzed water using response surface methodology. Poultry. Sci. 2015, 94, 2059-2065. [CrossRef]

33. Ni, L.; Cao, W.; Zheng, W.C.; Zhang, Q.; Li, B.M. Reduction of microbial contamination on the surfaces of layer houses using slightly acidic electrolyzed water. Poultry. Sci. 2015, 94, 2838-2848. [CrossRef]

34. Davidson, C.A.; Griffith, C.J.; Peters, A.C.; Fielding, L.M. Evaluation of two methods for monitoring surface cleanliness-ATP bioluminescence and traditional hygiene swabbing. Luminescence 1999, 14, 33-38. [CrossRef]

35. Latorre, A.A.; Van Kessel, J.S.; Karns, J.S.; Zurakowski, M.J.; Pradhan, A.K.; Boor, K.J.; Jayarao, B.M.; Houser, B.A.; Daugherty, C.S.; Schukken, Y.H. Biofilm in milking equipment on a dairy farm as a potential source of bulk tank milk contamination with Listeria monocytogenes. J. Dairy. Sci. 2010, 93, 2792-2802. [CrossRef]

Publisher's Note: MDPI stays neutral with regard to jurisdictional claims in published maps and institutional affiliations.

(C) 2020 by the authors. Licensee MDPI, Basel, Switzerland. This article is an open access article distributed under the terms and conditions of the Creative Commons Attribution (CC BY) license (http://creativecommons.org/licenses/by/4.0/). 